\title{
Estimation of Evapotranspiration and Water Budget Components Using Concurrent Soil Moisture and Water Table Monitoring
}

\author{
Mandana Rahgozar, ${ }^{1}$ Nirjhar Shah, ${ }^{2}$ and Mark Ross ${ }^{3}$ \\ ${ }^{1}$ Division of Facilities Planning, Design, and Construction, Pinellas County Schools, 11111 Belcher Road, Largo, FL 33773, USA \\ ${ }^{2}$ Environment and Infrastructure Division, Department of Civil and Water Resources, AMEC Inc., 2000 E. Edgewood Drive, \\ Lakeland, FL 33803, USA \\ ${ }^{3}$ Center for Modeling Hydrologic and Aquatic Systems and Department of Civil and Environmental Engineering, \\ University of South Florida, 4202 E. Fowler Avenue, Tampa, FL 33620, USA
}

Correspondence should be addressed to Nirjhar Shah, nirjhar.shah@amec.com

Received 6 December 2011; Accepted 29 January 2012

Academic Editor: L. D. Chen

Copyright ( $) 2012$ Mandana Rahgozar et al. This is an open access article distributed under the Creative Commons Attribution License, which permits unrestricted use, distribution, and reproduction in any medium, provided the original work is properly cited.

\begin{abstract}
Simultaneous measurements of soil moisture profiles and water table heads, along a flow path, were used to determine evapotranspiration (ET) along with other components of the water budget. The study was conducted at a small-scale $\left(\sim 0.8 \mathrm{Km}^{2}\right)$ hydrologic monitoring field site in Hillsborough County, Florida, from January 2002 to June 2004. Frequency Domain Reflectometry soil moisture probes, installed in close proximity to water table monitoring wells were used to derive changes in the soil water storage. A one-dimensional transect model was developed; changes in the soil water storage and water table observations served as input to determine all vertical and lateral boundary fluxes along the shallow water table flow plane. Two distinct land cover environments, grassland and an alluvial wetland forest, were investigated in this particular study. The analysis provided temporally variable ET estimates for the two land covers with annual totals averaging $850 \mathrm{~mm}$ for grassland, to $1100 \mathrm{~mm}$ for the alluvial wetland forest. Quantitative estimates of other components of a water budget, for example, infiltration, interception capture, total rainfall excess, and runoff were also made on a quarterly and annual basis. Novelty of this approach includes ability to resolve ET components and other water budget fluxes that provide useful parameterization and calibration potential for predictive simulation models.
\end{abstract}

\section{Introduction}

It is often useful in modeling or other hydrological studies to quantify components of a water budget. For upland and wetland settings water budgets are driven principally by precipitation $(P)$ and evapotranspiration (ET). Given the magnitude of ET relative to other processes, for example, infiltration and runoff, quantification of ET for different land cover types is critical to transient hydrologic analysis [1]. Understanding of the contribution of ET from different sources, for example, interception, shallow and deep soil is very valuable for simulation modeling [2]. Accurate measurement of ET components is, however, difficult and unreliable [3]. In humid regions such as West-Central Florida, ET is estimated to be $70 \%$ of precipitation on an average annual basis [4-6]. Despite its significance, ET is traditionally inferred from values of potential ET (PET) or reference ET
[7]. PET data are more readily available and can be computed from either pan evaporation or from energy budget methods (e.g., [8-11], etc.). The above methodologies, though simple, suffer from the fact that meteorological data collected in the field for PET are mostly under nonpotential conditions, rendering ET estimates as erroneous $[1,12]$.

Lysimeters can be used to determine ET from mass balance, however, for shallow water table environments, they are found to give erroneous readings due to air entrapment [13], as well as fluctuating water table [14]. Remote sensing techniques used in studies such as Kite and Droogers [15] and Mo et al. [16] are especially useful for large-scale studies. However, in case of highly heterogeneous landscapes the resolution of ET may become problematic owing to the coarse resolution of the data [3]. The energy budget or eddy correlation methodologies are also limited to computing net ET and cannot resolve ET contribution from different sources. 


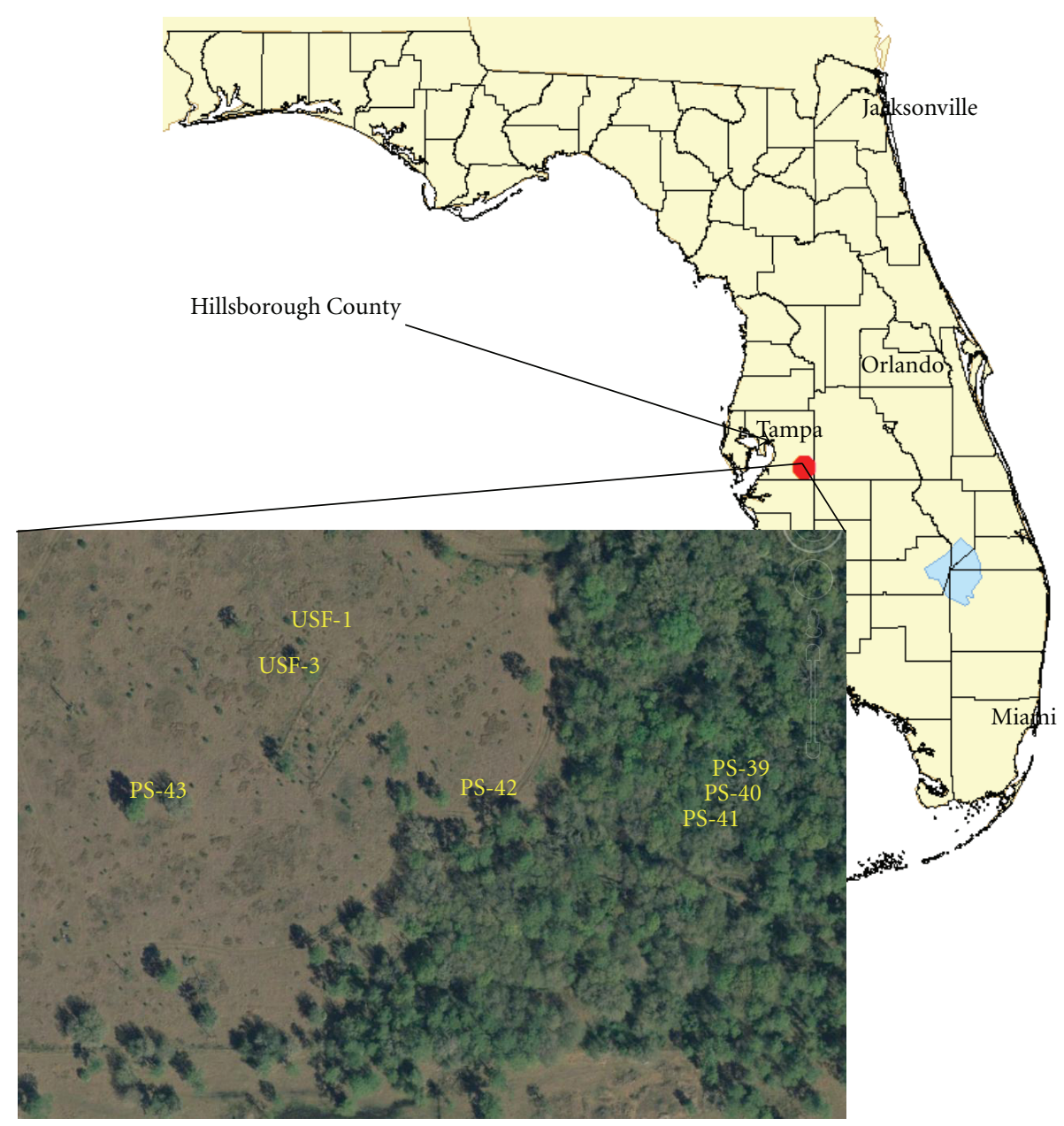

FIGURE 1: Location of the study site in Hillsborough County, Florida.

Recently, Sumner [1] provided a detailed review of the approximations used in the calculation of ET, and based on eddy correlation measurements recommended values of vegetation coefficients to be used to reduce PET to ET. The coefficients though simple to use in hydrologic models are more a function of ambient water content and particular seasonal rainfall pattern at the time of measurement rather than actual plant tendencies. Hence, during periods of excessive rainfall they may underpredict the actual ET. Therefore, the use of these coefficients is primarily restricted to areas with similar climatic pattern and water table conditions.

For shallow water table environments, continuous soil moisture measurements have been found to accurately determine ET [3, 17]. Past studies, for example, Robock et al. [18], Mahmood and Hubbard [19], and Nachabe et al. [3], have clearly shown that soil moisture monitoring can be successfully used to determine ET from a hydrologic balance. The current study aims at extending the above methodologies to determine other components of water budget such as lateral flow, infiltration, interception capture, storage, surface runoff, and other fluxes. The main objectives of this study were to (1) introduce a methodology to estimate spatiotemporal distribution of ET as a function of changes in soil moisture from near surface to saturation depth and fluctuating water table with sensitivity to landuse, (2) develop a one-dimension (1D) hydrologic model to quantify constituents of the water budget, and (3) study variation of hydrologic fluxes also with changes in land use.

The approach herein involves the use of soil moisture and water table data collected at different locations along a flow path. A one-dimensional transect model was developed and different conditions were specified at the boundaries of the model to quantify all vertical and horizontal fluxes. The inclusion of water table and soil moisture fluctuation in the model for ET estimation facilitates calculation of storage and head changes from which fluxes can be derived. Simultaneous measurement of metrological stresses permits evaluation of near instantaneous interactions of hydrologic processes in response to meteorological stresses and further enhances our understanding of ET flux.

\section{Materials and Methods}

2.1. Study Site. The site for this particular study was located in the subbasin of Long Flat Creek, a tributary of the Alafia River, adjacent to the Tampa Bay regional reservoir, in Lithia, Florida. Figure 1 shows the regional and aerial view of the site location. Two sets of monitoring well transects were 


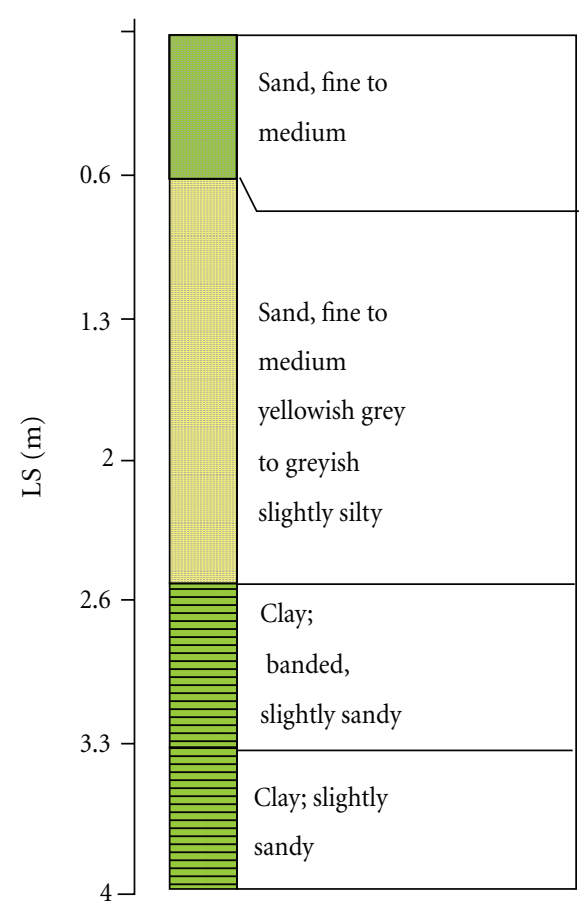

(a)

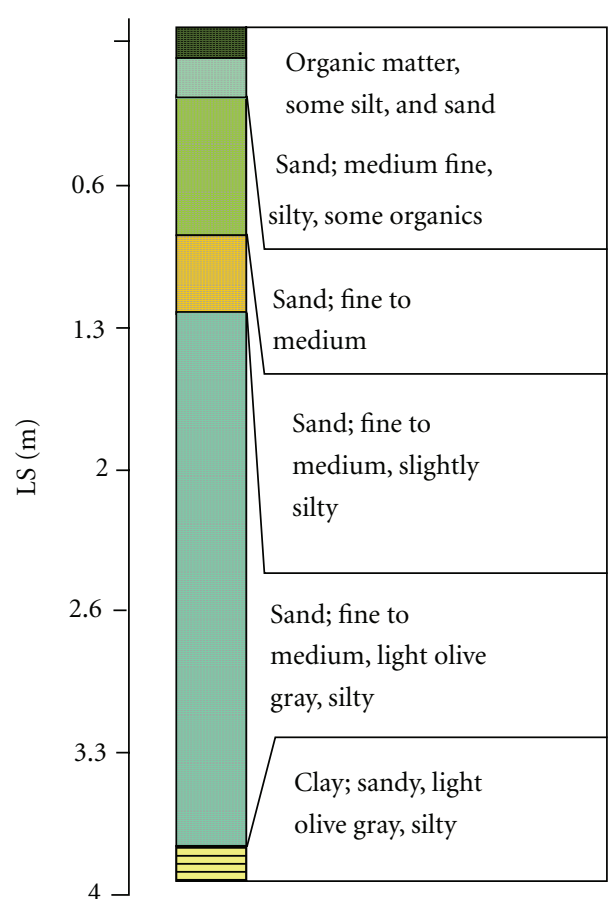

(b)

FIgURE 2: Soil stratigraphy from cores near (a) PS-39 and (b) PS-43.

installed on the west side of Long Flat Creek. One set of wells designated as PS-39, PS-40, PS-41, PS-42, and PS43 ran from east to west while the other set consisting of two wells, USF-1 and USF-3, were roughly parallel to the stream (Long Flat Creek), running in the North South direction.

The topography of the area slopes towards the stream with PS-43 being located at roughly the highest point for both transects. The vegetation varied from ungrazed Bahia grass in the upland areas (in proximity of PS-43, USF1 , and USF-3), to alluvial wetland forest comprising of the typical slash pine/hardwood trees near the stream. The ungrazed Bahia grass is a course textured, warm season, drought-tolerant pasture grass which survives in a variety of soils from sandy to clay. It is a prolific grower with deep and extensive root system which can extend as deep as 2.5 to $3 \mathrm{~m}$ into the soil in deeper water table settings. Slash pine (Pinus elliottii) is naturally found in wet flat woods, swampy areas, and shallow pond edges. Slash pine is a medium-to-large tree that reaches heights of $25 \mathrm{~m}$ to $40 \mathrm{~m}$. Hardwood tree characteristics are medium-to-large size trees with a height of $13 \mathrm{~m}-21 \mathrm{~m}$. Shrubs and groundlevel plants are few. Green foliage density follows a seasonal pattern, reaching maximum coverage during the summer wet periods and minimum coverage during the winter dry periods.

The area close to PS- 42 is characterized as a mixed zone. Horizontal distance between the wells is approximately $16,22,96,153 \mathrm{~m}$ from PS-39 to PS-43, with PS-39 being approximately $6 \mathrm{~m}$ from the creek. Horizontal distance between USF-1 and USF- 3 was $33 \mathrm{~m}$. All wells were surveyed and land surface elevations were determined with respect to National Geodetic Vertical Datum 1929 (NGVD).

Extensive soil investigations were performed on soil cores taken from the study site. The soil in the study area is primarily Myakka fine sand (of marine origin) with high permeability $\left(10^{-1}\right.$ to $\left.10 \mathrm{~m} / \mathrm{d}\right)$ in the surface and subsurface layers [20]. Figures 2(a) and 2(b) shows sample soil stratigraphy obtained from two cores taken from the study site close to wells PS39 and PS43. The results of soil sampling at number of locations along the East West as well as North South transect showed that the soil was primarily sand with presence of a clay layer at a depth that varied from $4 \mathrm{~m}$ below that land surface in the upland regions to about $2.5 \mathrm{~m}$ below the land surface near the stream. Detailed information on soil and site characteristics can be found in Thompson [21] and Trout and Ross [22]. Apart from the study-specific tests, information about extent of the confining clay layer, hydraulic conductivity values of the confinement, and head differences between surficial and intermediate aquifer were obtained from the geotechnical and site characterization report [23] prepared as a part of the construction of Tampa Bay regional reservoir. The report indicates (Refer to volume 1 Section 3) that thickness of clay layer average around $3-5 \mathrm{~m}$ with average head differences between the surficial and intermediate aquifer being approximately $6 \mathrm{~m}$. The hydraulic conductivity values - as determined by slug test and deep aquifer performance tests-for the confining clay layer varied from $10^{-4} \mathrm{~m} /$ day to $10^{-5} \mathrm{~m} /$ day. The lower confining layer can hence be assumed as an impermeable layer. Data collection for the study was done from January, 2002 through June 2004. 


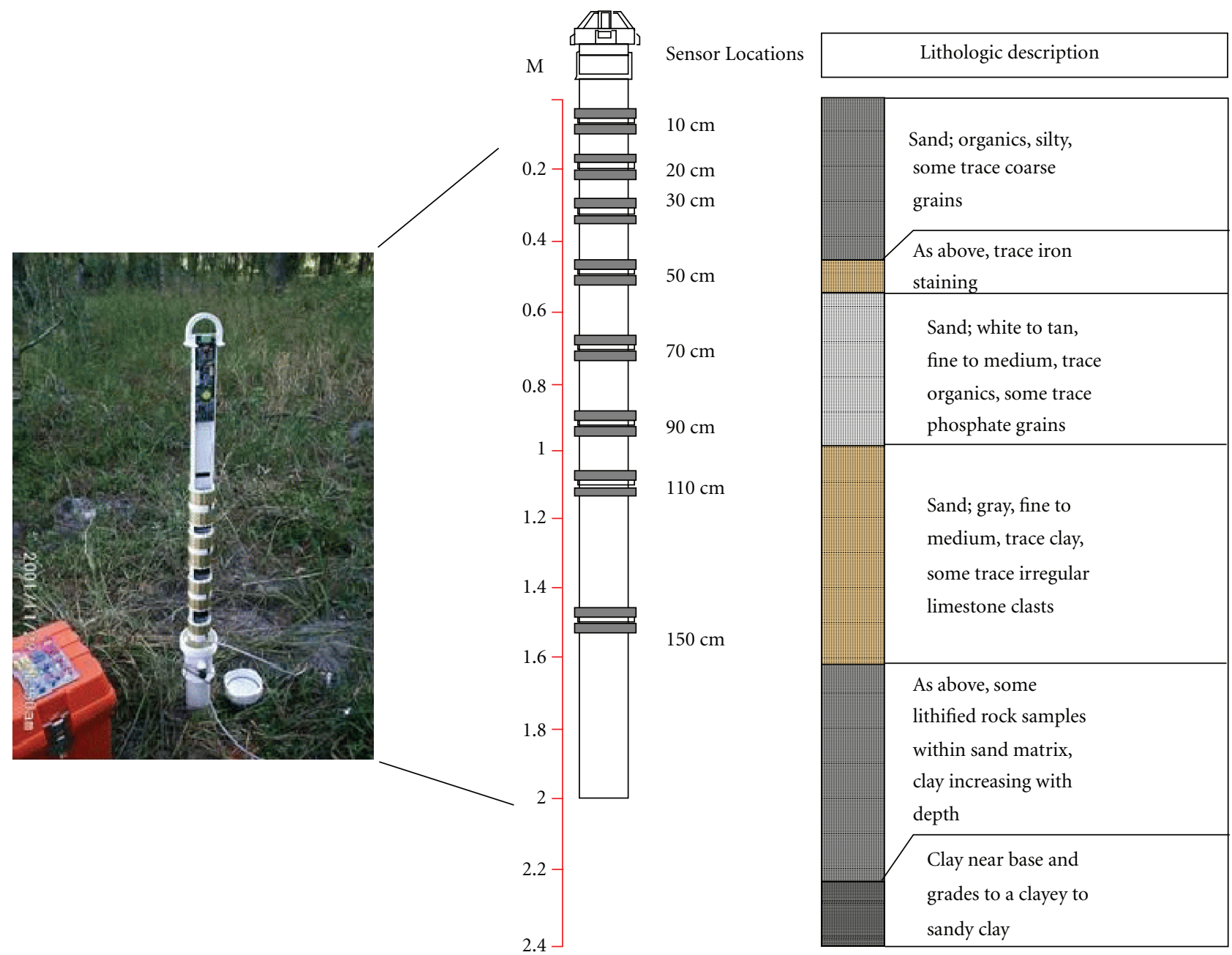

FIGURE 3: Example soil moisture probe setup and soil stratigraphy at one study site.

2.2. Instrumentation. All transect wells housed Instrumentation Northwest (Kirkland, WA) $0-34 \mathrm{kPa}$ (0-5 psi) submersible pressure transducers, accurate to $0.034 \mathrm{kPa}$ (0.005 psi). Adjacent to each well, an EnviroSMART soil moisture probe (Sentek Pty. Ltd., Adelaide, Australia) equipped with eight sensors at varying depths was installed (Figure 3). The soil moisture sensors allowed measurement of moisture content along a vertical profile at different depths from land surface. The sensors were deployed at 10, 20, 30, $50,70,90,110$, and $150 \mathrm{~cm}$ from the land surface. The sensors work on the principle of frequency domain reflectometry (FDR) to convert electrical capacitance shift to volumetric water content ranging from oven dryness to saturation with a resolution of $0.1 \%$ [24]. Default factory calibration equations were used for calibrating these sensors. Fares and Alva [17] and Morgan et al. [25] found no significant difference in the values of observed recorded water content from the sensors when compared with the manually measured values.

In addition to pressure transducers and soil moisture probes, stream gages were placed at three locations in the adjacent perineal creek (Long Flat Creek). Two tipping bucket and two manual rain gages were also installed to record the amount of precipitation. All pieces of equipments were installed according to National Weather Service or USGS Standard where applicable. The data were collected on 5-minute intervals (instantaneous) and were accumulated to hourly values (rainfall was summed while everything else is averaged).

In case of missing water table elevation data from a particular location, interpolation of water table heads from the adjacent station was used to complete the record. For soil moisture data, however, no attempt was made to simulate the missing data. Instead, a different methodology, relying on water table observations and a variable specific yield model [26], calibrated for the site, was used to derive storage changes. Data gaps were, however, infrequent and comprised less than $5 \%$ of the data record. During the entire study period the water table was found to fluctuate between land surface and a maximum depth of about $140 \mathrm{~cm}$ for all well locations. The deepest water table conditions were observed at PS39.

2.3. One-Dimensional Transect Model. Two separate transect models were developed, one for wells PS-39 to PS-43 and one 


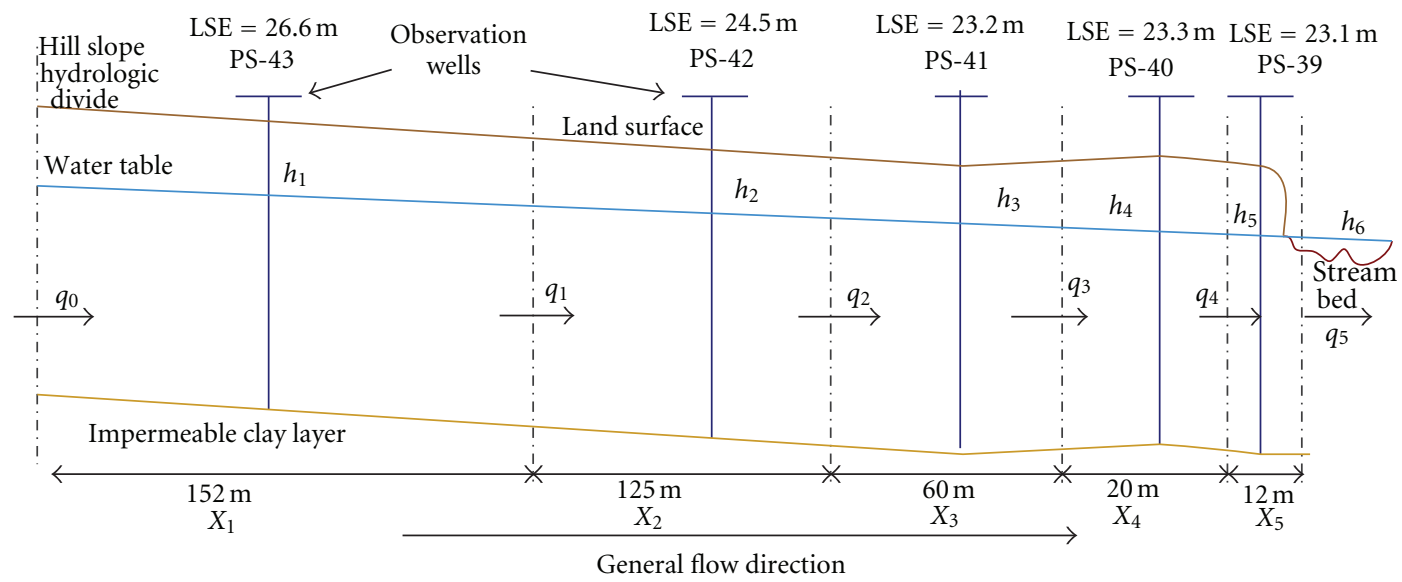

$X_{i}=$ Grid cell " $i$ "

LSE $=$ Land surface elevation at well location

FIgURE 4: One-dimensional transect model for well transect PS-39 to PS-43 (not to scale).

TABLE 1: Notation used in the 1D transect model along with description and units of each symbol.

\begin{tabular}{|c|c|c|c|c|c|}
\hline Notation & Description & Units & Notation & Description & Units \\
\hline$P$ & Precipitation & {$\left[\mathrm{LT}^{-1}\right]$} & $\tau_{i}$ & $\begin{array}{l}\text { Effective flow thickness in } \\
\text { the } i \text { th grid cell }\end{array}$ & {$[\mathrm{L}]$} \\
\hline$d_{\mathrm{WT}}$ & Depth to the water table & {$[\mathrm{L}]$} & $P_{E}$ & Effective rainfall & {$\left[\mathrm{L}^{3} \mathrm{~L}^{-2}\right]^{*}$} \\
\hline ET & Evapotranspiration & {$\left[\mathrm{LT}^{-1}\right]$} & $I_{C}$ & Interception capture & {$\left[\mathrm{L}^{3} \mathrm{~L}^{-2}\right]^{*}$} \\
\hline$I$ & Infiltration & {$\left[\mathrm{LT}^{-1}\right]$} & URI & $\begin{array}{l}\text { Upstream runoff } \\
\text { infiltration }\end{array}$ & {$\left[\mathrm{L}^{3} \mathrm{~L}^{-2}\right]^{*}$} \\
\hline$I_{S}$ & Daily soil infiltration & {$\left[\mathrm{L}^{3} \mathrm{~L}^{-2}\right]^{*}$} & DS ET & $\begin{array}{l}\text { Evapotranspiration from } \\
\text { depression storage }\end{array}$ & {$\left[\mathrm{L}^{3} \mathrm{~L}^{-2}\right]^{*}$} \\
\hline $\mathrm{ET}_{S}$ & Evapotranspiration from soil moisture & {$\left[\mathrm{LT}^{-1}\right]$} & TET & Total evapotranspiration & {$\left[\mathrm{L}^{3} \mathrm{~L}^{-2}\right]^{*}$} \\
\hline$q$ & Specific lateral discharge & {$\left[\mathrm{L}^{3} \mathrm{~L}^{-1} \mathrm{~T}^{-1}\right]$} & TRE & Total rainfall excess & {$\left[\mathrm{L}^{3} \mathrm{~L}^{-2}\right]^{*}$} \\
\hline$S$ & Water storage in the soil column per unit width & {$\left[\mathrm{L}^{3} \mathrm{~L}^{-1}\right]$} & NR & Net runoff & {$\left[\mathrm{L}^{3} \mathrm{~L}^{-2}\right]^{*}$} \\
\hline$\theta$ & Water content & {$\left[\mathrm{L}^{3} \mathrm{~L}^{-3}\right]$} & $\mathrm{HR}$ & Hortonian runoff & {$\left[\mathrm{L}^{3} \mathrm{~L}^{-2}\right]^{*}$} \\
\hline$\Delta X_{i}$ & lateral dimension of $i$ th grid cell & {$[\mathrm{L}]$} & SER & Saturation excess runoff & {$\left[\mathrm{L}^{3} \mathrm{~L}^{-2}\right]^{*}$} \\
\hline$K$ & Hydraulic conductivity & {$\left[\mathrm{LT}^{-1}\right]$} & $I_{S}$ & Soil infiltration & {$\left[\mathrm{LT}^{-1}\right]$} \\
\hline
\end{tabular}

*Accumulated on daily time step.

for wells USF-1 to USF-3. The first model was set up with five grid cells, with the location of the observation wells being the center of each of the grid cells and the observed values representative of the whole grid. Transect's upland flowdivide comprised one boundary (no flow) and the center of the stream with variable stage comprised the other (stage boundary). Flows at each internal cell boundary were derived from nodal (cell centered) observed records and a simple Darcian flow calculation. Figure 4 shows the transect model for wells PS-39 to PS-43 with details about land surface elevation, distances between the wells, and so forth.

For both transects, the upper boundary was the land surface and the lower boundary was conceptualized as a no-flow boundary condition, quite appropriate for the contiguous lower clay layer of the surficial aquifer at the site $[22,23]$. The flow thicknesses were determined from the depth to the water table the local depth to the underlying clay confinement. The flow occurring along the transect was assumed to be uniform (nonconvergent) across the width of the model.

For each grid cell the equivalent hydraulic conductivity obtained from the laboratory measurements (refer to Section 2.3.1) was used in the application of the mass balance equations. The following paragraphs summarize the basis of the one-dimensional transect model used to derive ET. Table 1 lists the notation with description and dimensions of each of the symbol used.

The water budget equation for the model can be written as

$$
\left[i_{S}-\mathrm{ET}_{S}\right] \Delta X=\frac{\Delta S}{\Delta t}+\Delta q
$$

where is $\left[\mathrm{L}^{3} \mathrm{~L}^{-2} \mathrm{~T}^{-1}\right]$ represents soil infiltration, $\mathrm{ET}_{S}$ $\left[\mathrm{L}^{3} \mathrm{~L}^{-2} \mathrm{~T}^{-1}\right]$ is soil moisture evapotranspiration from the soil column, $\Delta X$ is the lateral dimension of a grid cell (Figure 4), 
$\Delta q\left[\mathrm{~L}^{3} \mathrm{~L}^{-1} \mathrm{~T}^{-1}\right]$ is net lateral flow from the adjoining cell(s), $\Delta S$ is change in total storage of water in the gird cell $\left[\mathrm{L}^{3} \mathrm{~L}^{-1}\right]$ per unit width, and $\Delta t[\mathrm{~T}]$ represents the time step (one hour).

As the maximum depth to the water table $\left(d_{\mathrm{WT}}\right)$ was $140 \mathrm{~cm}$, changes in the water storage in any grid cell can be effectively inferred by integrating the observed soil moisture through the soil profile $(0-155 \mathrm{~cm})$ and subtracting the consecutive storage values in time. Trapezoidal rule of numerical integration was used to calculate the total soil moisture from the observed values from the sensors for each time step. Mathematically the changes in storage per unit width at any time " $t+\Delta t$ " from time " $t$ " for a given grid cell " $i$ " of lateral dimension $\Delta X_{i}[\mathrm{~L}]$ can be computed as

$$
\Delta S(t+\Delta t)_{i}=\left(\int_{0}^{\lambda} \theta(z, t+\Delta t) d z-\int_{0}^{\lambda} \theta(z, t) d z\right) \Delta X_{i},
$$

where $\lambda[\mathrm{L}]$ is a fixed depth of soil which for all the wells was $155 \mathrm{~cm}$.

From recorded values of $d_{\mathrm{WT}}$ and known land surface elevation, water table head, $h_{i}$ (at any cell " $i$ "), with respect to NGVD, can be computed. Hence, using Darcy's Law with computed values of equivalent hydraulic conductivity, $\bar{K}_{i}$ $\left[\mathrm{LT}^{-1}\right]$, for a given grid cell " $i$ ", flow from cell " $i-1$ " to cell " $i$ ", $q_{i-1}$ at any time " $t$ ", can be computed as

$$
q_{i-1}=-\bar{K}_{i} \bar{\tau}_{i}\left[\frac{h_{i}^{t}-h_{i-1}^{t}}{\Delta X_{i}}\right],
$$

where $\bar{\tau}_{i}[\mathrm{~L}]$ is the effective flow thickness for the cell, which is the difference between the water table elevation and the elevation of the confining clay layer at each time step. Other symbols are as previously defined. By simply changing the parameters, flow from cell " $i$ " to cell $i+1, q_{i}$ can be similarly computed. For the last cell (PS-39), however, the stream stage was used as the head value to compute the lateral flow going into or coming from the stream. Net lateral flow into cell " $i$ " can thus be calculated as in

$$
\Delta q_{i}^{t}=q_{i-1}^{t}-q_{i}^{t}
$$

In a given time step (for current study it is hourly), depending on the algebraic sum of terms on the right-hand side of (1), either soil infiltration or soil evapotranspiration is assumed to be occurring. An inherent assumption made here is that, since small time intervals (hourly) were used for the analysis, either evapotranspiration or infiltration took place in a given time step. $\mathrm{ET}_{S}$ is representative of direct soil evaporation and (or) plant transpiration from the soil column. $\mathrm{ET}_{S}$ values from soil moisture change, for each cell and for each hour, are summed up over a 24hour period (midnight to midnight) to get an estimate of daily soil moisture ET (daily $\mathrm{ET}_{S}$ ) from that grid cell. To determine total ET (TET), depression storage ET (DS ET), and interception ET $\left(I_{C}\right.$ ET) (explained in Sections 2.4.5 and 2.4 .1 resp.) are also added to daily $\mathrm{ET}_{s}$. On the other hand, soil infiltration values were associated directly to observed
TABLE 2: Values of hydraulic conductivity obtained from permeameter analysis done on soil core samples taken at different depths below land surface (Adapted from Thompson [21]).

\begin{tabular}{lcc}
\hline $\begin{array}{l}\text { Location } \\
\text { (closest well) }\end{array}$ & $\begin{array}{c}\text { Mean depth below LS } \\
(\mathrm{m})\end{array}$ & $\begin{array}{c}\text { Hydraulic } \\
\text { conductivity } \\
(\mathrm{m} / \text { day })\end{array}$ \\
\hline \multirow{2}{*}{ USF-1 } & 0.76 & 1.33 \\
& 1.11 & 0.084 \\
& 1.675 & $2.72 \mathrm{E}-04$ \\
\hline USF-3 & 0.61 & 0.44 \\
& 1.11 & 0.08 \\
& 1.98 & $2.20 \mathrm{E}-04$ \\
PS43 & 2.27 & $1.67 \mathrm{E}-04$ \\
\hline PS42 & 0.45 & $5.60 \mathrm{E}-02$ \\
& 1.675 & $3.30 \mathrm{E}-01$ \\
& 2.89 & $4.10 \mathrm{E}-01$ \\
& 3.5 & $3.79 \mathrm{E}-04$ \\
\hline PS39/PS40 & 0.45 & $1.23 \mathrm{E}+00$ \\
& 0.99 & $3.50 \mathrm{E}-01$ \\
& 1.145 & $4.20 \mathrm{E}-02$ \\
& 2.34 & $3.30 \mathrm{E}-02$ \\
\hline & 0.54 & $2.00 \mathrm{E}-01$ \\
& 1.15 & $1.27 \mathrm{E}-03$ \\
& 2.36 & $1.05 \mathrm{E}-04$ \\
\hline & 0.125 & 1.03 \\
& 0.3 & 0.64 \\
& 2.89 & $1.40 \mathrm{E}-04$ \\
\hline
\end{tabular}

precipitation and (or) upstream runoff infiltration (refer to Section 2.4.3). Like the $\mathrm{ET}_{S}$ values soil infiltration $\left(I_{S}\right)$ was further aggregated (summed up) over 24 hours to determine daily soil Infiltration $\left(I_{S}\right)$, which is used to find other water budget components such as total rainfall excess and runoff (refer to Section 2.4).

2.3.1. Estimation of Hydraulic Conductivity. To better understand the geology and soil conditions at the study site several undisturbed soil samples were collected using hydraulic coring machine (GeoProbe). The samples were then analyzed to determine the stratigraphy. Section of soil cores corresponding to each stratum were then cut and wetted to saturate them completely. Falling head permeameter analysis was done to determine the saturated hydraulic conductivity $(K)$ of the samples. For specific details about permeameter tests and other soil analyses refer to Thompson [21]. Table 2 shows the depths and corresponding values of hydraulic conductivity values obtained for samples close to different well locations. Each soil strata was assumed to be isotropic and hence within a given strata of soil the vertical hydraulic conductivity was assumed to be the same as the horizontal hydraulic conductivity. Using this assumption, equivalent horizontal saturated hydraulic conductivity can 
be determined using a distance weighted average of hydraulic conductivity from each layer

$$
\bar{K}=\frac{\sum K_{i} d z}{\sum d z},
$$

where $d z$ is the depth of each strata, $K_{i}$ is the corresponding values of saturated hydraulic conductivity and, $\bar{K}$ as defined above, is the equivalent hydraulic conductivity. At any time step, depending on the depth to the water table, the zone of saturation is determined and based on the saturated soil layers equivalent value of hydraulic conductivity is calculated.

Apart from the permeameter test, in situ slug tests were done to determine the general hydraulic conductivity of the surficial aquifer. The results of the slug test were analyzed using the Bower-Rice [27] as well as the Hvorslev [28] method. The results indicated the horizontal hydraulic conductivity of the aquifer varied between around $0.5 \mathrm{~m} /$ day to $0.1 \mathrm{~m}$ /day which is within $10-15 \%$ of the laboratory obtained values. Further details about the results are available in Thompson [21].

2.4. Estimation of Lateral and Vertical Fluxes. The onedimensional transect model was run on hourly time steps to calculate the lateral flow, soil infiltration and soil moisture ET. Soil moisture, evapotranspiration, and infiltration were then aggregated over 24 hours to determine the values of daily $\mathrm{ET}_{S}$ and daily soil infiltration $\left(I_{S}\right)$. Using these aggregated daily values and the procedure described in the following subsections, other water budget components were calculated on a daily time step.

2.4.1. Interception Capture $\left(I_{C}\right)$. Interception capture is the initial abstraction from a rainfall event. If there is no runoff accompanying a given rainfall event, then, theoretically, it can be estimated by subtracting the observed rainfall from the observed infiltration.

In the absence of any direct measurement of runoff, interception capture can be estimated by selecting isolated events with intensity less than the hydraulic conductivity of the surface soil layers, occurring after medium to dry antecedent conditions (in deeper water table conditions). For this particular study, for each well individual rainfall events which satisfied the-above mentioned criteria were manually selected and plotted against the observed soil infiltration for each event. The intercept of the best fit line on the precipitation versus infiltration curve yields an estimate of the interception capture $\left(I_{C}\right)$ for each well. The obtained values were averaged for similar land use covers, PS43, USF3, and USF1 for grassed land cover and PS42, PS41, PS40, and PS39 as forested land cover) to determine grassland and forested wetland $I_{c}$, respectively.

2.4.2. Effective Precipitation $\left(P_{E}\right)$. On a daily time step effective precipitation $\left(P_{E}\right)$ is defined as the difference between the cumulative precipitation (from midnight to midnight) and the interception capture

$$
P_{E}=\sum_{24 \mathrm{hrs}} P-I_{C},
$$

where $P\left[\mathrm{LT}^{-1}\right]$ is the recorded precipitation, and $I_{C}[\mathrm{~L}]$ is the interception capture. If $P$ was less than $I_{C}, P_{E}$ was assumed to be zero.

2.4.3. Upstream Runoff Infiltration (URI). For any well location if soil infiltration $\left(I_{S}\right)$ is greater than the effective precipitation $\left(P_{E}\right)$, the difference between the two is assumed to correspond to upstream runoff infiltration (URI). Mathematically it can be written as

$$
\mathrm{URI}= \begin{cases}I_{S}-P_{E} & \text { if } I_{S}>P_{E} \\ 0, & \text { otherwise }\end{cases}
$$

2.4.4. Infiltration (I). Daily infiltration (I) is defined as the difference between daily soil infiltration and upstream runoff infiltration. The value indicates how much of the water from the rainfall actually went in to the ground and is useful when quantifying runoff

$$
I=I_{S}-\mathrm{URI}
$$

2.4.5. Depression Storage ET (DS ET). It is known that when the water table is close to the land surface, such that the capillary fringe (zone of tension saturation) starts intersecting the land surface (i.e., $d_{\mathrm{WT}}<$ capillary fringe), the evapotranspiration occurs at potential [29]. However, for most of the time under such conditions, the changes recorded by the soil moisture sensors indicate a daily $\mathrm{ET}_{S}$ value which is less than the value of PET minus $I_{C}$. The primary reason for this can be attributed to the free surface evaporation taking place from small-scale surface depressions. Thus, the difference in the daily $\mathrm{ET}_{S}$ and PET minus $I_{C}$ during these periods is attributed to depression storage ET, wherein the ET demand is also met by evaporation of water stored in the land surface depressions.

To calculate ET from depression storage it is assumed that ET occurs at potential ET (PET) rate when the depth to water table is less than capillary fringe value. A number of methods for estimation of potential ET can be used. For this particular study owing to its simplicity and limited data to support more elaborate methods the Jensen and Haise (J\&H) [30] method was used to estimate PET. The model equation is presented in

$$
\operatorname{PET}_{\text {J\&H }}=\left[\frac{R_{S}}{2450} \times\left(\left(0.025 \times T_{\text {ave }}\right)+0.08\right)\right] .
$$

The input parameters to get hourly values of $\mathrm{PET}_{\mathrm{J} \& \mathrm{H}}$ are solar radiation $\left(R_{S}\right)\left(\mathrm{kJ} / \mathrm{m}^{2} / \mathrm{hr}\right)$ and average temperature $\left(T_{\text {ave }}\right)\left({ }^{\circ} \mathrm{C}\right)$. The hourly values were used to generate hourly values of $\mathrm{PET}_{\mathrm{J} \& \mathrm{H}}$. At the study site, a USGS standard class A pan and a weather station measuring solar radiation, temperature, barometric pressure, wind speed, and relative humidity were installed and monitored. The pan and weather data collection, for measurement of PET was not complete and resolved sufficiently for the period. The site measured data were, therefore, further supplemented with National Weather Service (NWS) Ona station (NWS station 
no. 086539-4) record. A constant pan factor of 0.7 was used to reduce the $\mathrm{PET}_{\mathrm{J} \& \mathrm{H}}$ values to potential ET (PET) values appropriate for the study site [2].

From a field study, Said et al. [26] found that, on average, the capillary fringe value for the soils in the study area (for all land covers) was uniform and approximately $0.3 \mathrm{~m}$. Therefore, the depth to the water table threshold for assumption of evapotranspiration being at potential was set for all times when depth to the water table $\leq 0.3 \mathrm{~m}$. Mathematically for depth to the water table less than $0.3 \mathrm{~m}$, DSET can be calculated by

$$
\text { DSET }=\operatorname{PET}-I_{C}-\text { daily } \mathrm{ET}_{S} .
$$

It should be noted here that use of the Jensen and Haise method in this study introduces an uncertainty in the PET estimates. Hence it is important to analyze these uncertainties and their effects on the calculated magnitude of other fluxes. Section 3.1 discusses in detail the errors estimates of depression storage ET and its impact on the other water budget components.

2.4.6. Total ET (TET). Total ET (TET) was determined on daily basis by summing up the value of $\mathrm{ET}_{S}$, DS ET and interception capture $\left(I_{c}\right)$. The underlying assumption being that all the interception capture evaporates within one day, considered reasonable for the subtropical West Central Florida conditions at the study site [3].

2.4.7. Total Rainfall Excess (TRE). Total rainfall excess (TRE) is defined as the amount of effective precipitation that is not reflected as infiltration. For any time step, when the effective precipitation exceeds infiltration TRE can be computed as

$$
\mathrm{TRE}=P_{E}-I .
$$

2.4.8. Saturation Excess Runoff (SER), Hortonian Runoff (HR), and Net Runoff (NR). As mentioned previously in Section 2.4.5, the capillary fringe depth for the study site was found to be $0.3 \mathrm{~m}$. Therefore, if the $d_{\mathrm{WT}}$ is equal to or less than this value, then all of the rainfall excess is assumed to be contributing to Saturation Excess Runoff (SER). TRE is otherwise assumed to be associated with Hortonian Runoff (HR). Mathematically,

$$
\mathrm{TRE}= \begin{cases}\mathrm{SER} & \text { if } d_{\mathrm{WT}} \leq 0.3 \mathrm{~m} \\ \mathrm{HR} & \text { if } d_{\mathrm{WT}}>0.3 \mathrm{~m}\end{cases}
$$

On a daily basis, total rainfall excess may fill up surface depressions as well as run off downstream. Hence the amount of rainfall excess that runs off from a particular well (Net Runoff NR) and infiltrates downstream (as URI for a downstream well) and/or flows into the stream can be quantified using (13). If total rainfall excess was found to be smaller than DSET, NR was assumed to be zero

$$
\mathrm{NR}=\mathrm{TRE}-\mathrm{DS} \mathrm{ET} .
$$

The results obtained on a daily time scale using the above methodology were then aggregated to obtain quarterly values, for spring, summer, fall, and winter. In the results and discussion section, the winter quarter extends from the 1st day of January to the last day of March, spring includes the 1st day of April through the last day of June, the summer includes the 1st day of July through the last day in September and fall is the 1st day of October to the last day in December. Figure 5 shows the methodology as a process flow diagram, showing the interrelationships between different processes and the time scale of calculation of each component of the water balance equation.

2.5. Assumptions. Before discussing the results obtained from the analysis it is very important to categorically define the important assumptions used in the methodology. This will help the reader in deciding which of the assumptions hold true, as well as which assumptions have to be altered for successful adaptation of the above methodology at a different site with circumstances different from this specific research site.

(1) For any given small time step (hourly), it was assumed that changes in total soil moisture content were either net infiltration into the column or net evapotranspiration out of the soil column.

(2) The interception capture values for the land cover, grass, or forest were assumed to be constant on daily basis for all the quarters. However, they could be variable on a quarterly basis if data existed.

(3) On a daily basis interception capture is the initial abstraction from total rainfall which is bounded by an upper limit controlled by the vegetation and assumed to be totally evaporated before the start of the next day.

(4) No effective precipitation or infiltration was assumed for the case when the observed rainfall was less than or equal to the total daily magnitude of the $I_{C}$, for each land use.

(5) Owing to the low permeability of the confining clay layer leakage to intermediate aquifer was considered negligible. However it is believed that for environments with leaky aquifer, the methodology would still work by considering a constant leakage value on an hourly basis.

(6) Due to continual replenishment of soil moisture by shallow water table $\left(d_{\mathrm{WT}} \leq 0.3 \mathrm{~m}\right)$ when depression storage was present, the total ET was assumed to be PET $-I_{c}-\mathrm{ET}_{s}$ (10). Therefore, reasonable PET estimates must be made for very shallow water table conditions to obtain complete annual ET estimates.

(7) All runoff is assumed to be saturation excess runoff when the capillary fringe intersect land surface (e.g., $\left.d_{\mathrm{WT}} \leq 0.3 \mathrm{~m}\right)$.

(8) Some numerical noise filtering (e.g., 1-4 hr running average) was required due to small errors associated 


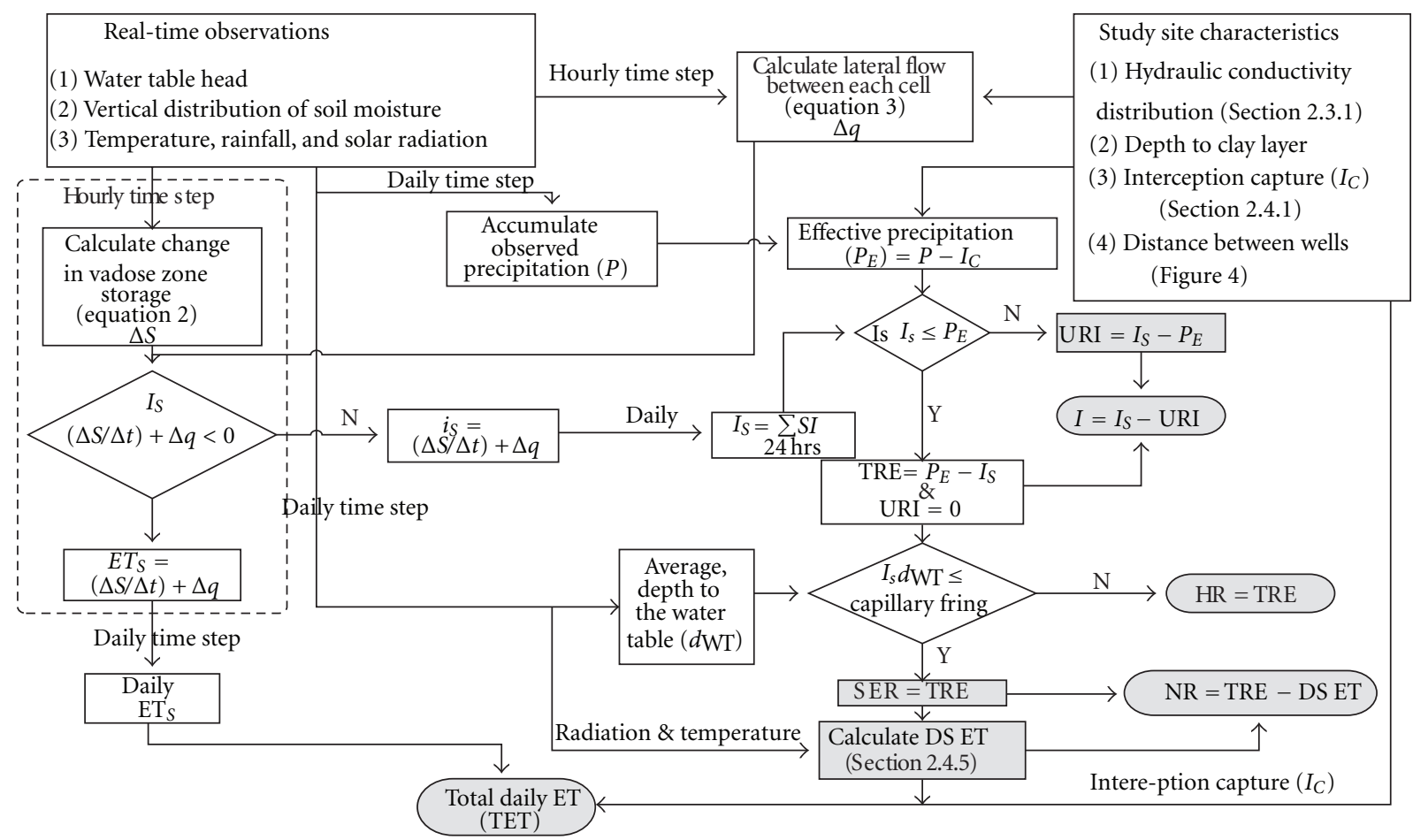

FIgURE 5: Process flow diagram showing the sequence of calculation of the water budget components. The grayed out boxes show the computed components. The area marked out by the dashed line represent the one-dimensional transect model running on hourly time steps.

with highly resolved data. This has the effect of slightly reducing the infiltration and ET estimates from this methodology. Comparison of results for the two sets of running averages revealed negligible effect in the overall results.

\section{Results and Discussion}

An important aspect of this methodology is the time scale of variation of the soil moisture storage with respect to external stresses. Figure 6(a) to 6(d) show the response of the soil moisture storage to different external factors: water table fluctuations, rainfall, and solar radiation. The figures show that soil moisture changes are very responsive (time scale of minutes) to imposed stresses. Also, integrated total storage, changes accumulated over time are very consistent with observed rainfall fluxes. Figure 6(b) shows that even at sub-hour time steps, changes in the solar radiation (due to passing clouds, etc.) caused variations in the soil moisture storage and corresponding root water uptake. Figures 6(c) and $6(\mathrm{~d})$ show the contrasting diurnal fluctuations of the soil moisture changes along with the water table for two locations, one in a forested area (PS41) and the other grassed (PS43). Finally, Figure 6(a) shows an example response of soil moisture increases due to multiple rainfall events followed by a series of corresponding declines in the absence of precipitation. It is noted that repeatedly the magnitude of total integrated soil moisture change is consistent with the observed rainfall totals (minus interception capture).
Overall, Figures 6(a) to 6(d) conclusively show that the soil moisture measurements can be used as an effective indicator (with high reliability) of soil moisture changes at the time scale of hours. Thus, a reliable degree of confidence in the use of soil moisture observations for deriving soil moisture fluxes can be expected.

Water budget components, calculated from the onedimensional transect model using soil moisture and water table observations from beginning of January 2002 till the end of June 2004 revealed that almost all components display a consistent seasonal behavior. Quarterly averaged observed fluctuations in $\mathrm{ET}_{S}$ (soil moisture ET), DS ET (depression storage ET), TET (Total ET), I (infiltration), TRE (Total rainfall excess), SER (Saturation excess runoff), and the $d_{\mathrm{WT}}$ (depth to the water table) are shown in Figures 7, 8, 9, 10, 11, 12,13 and 14 .

Figures 15(a) and 15(b) show the plot of precipitation versus infiltration for the determination of interception capture (as discussed in Section 2.4.1). The value of daily maximum interception capture from the y-intercept was found to be $1.3 \mathrm{~mm}$ for grassland and $2.5 \mathrm{~mm}$ for the flatwoods forested land cover. The values of interception capture found using the described methodology is consistent with values referenced in Viessman and Lewis [31, page 132]. From the annual water budget tables (Tables 3-5) the annual value of interception capture varied from 106 to $221 \mathrm{~mm}$.

Comparison of quarterly values of water budget components for different years shows some interesting behavior. Derived ET components varied by quarter but similarly 


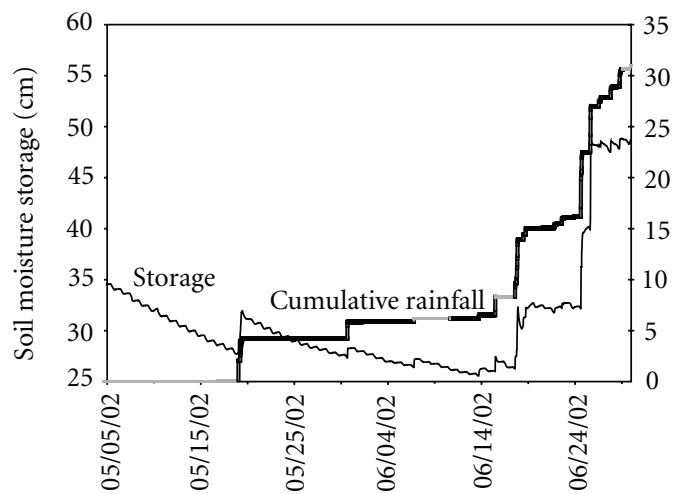

(a)

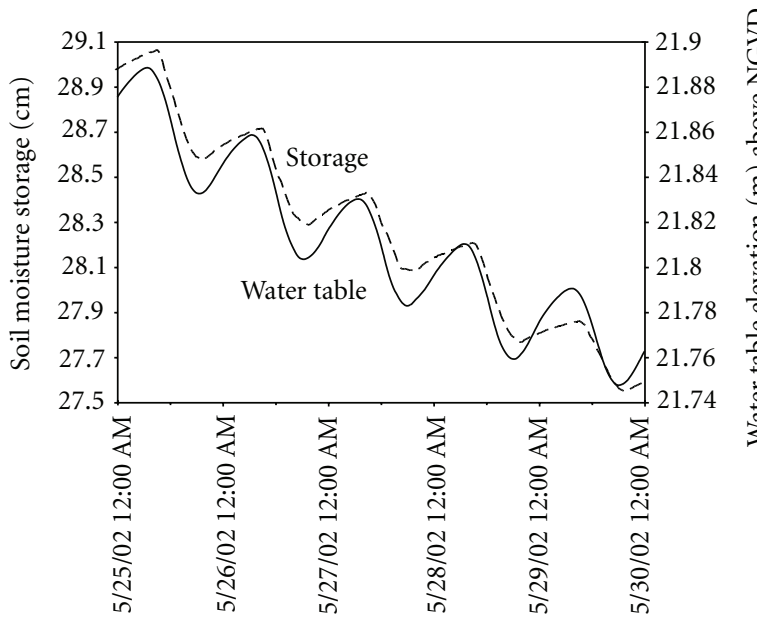

(c)

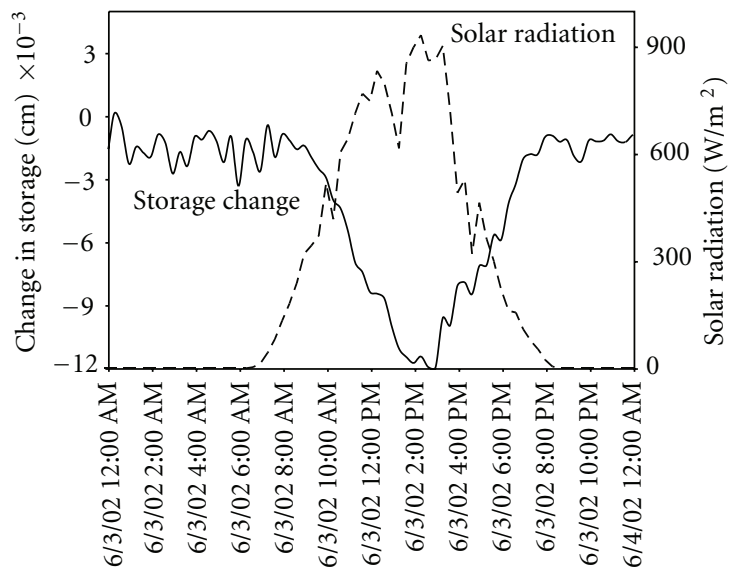

(b)

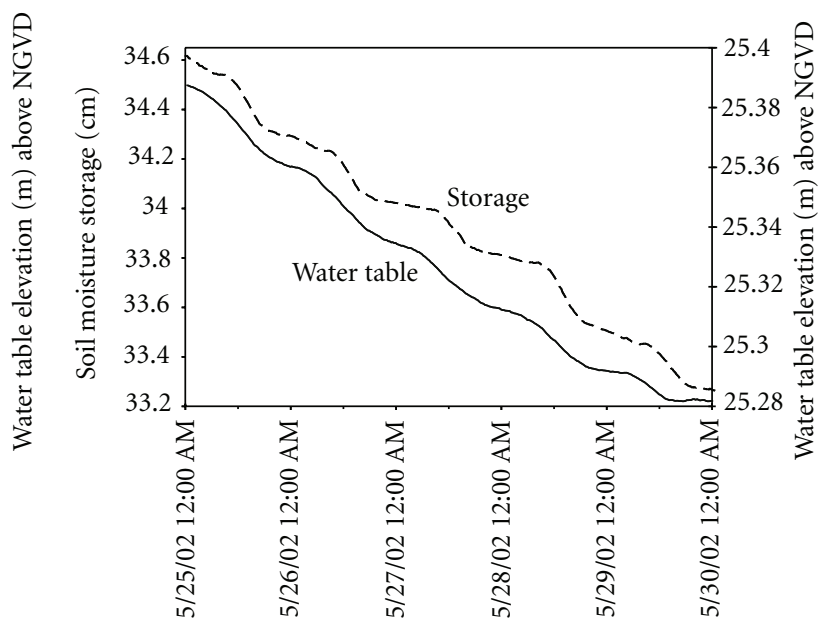

(d)

Figure 6: Variation of soil moisture storage due to different stresses. (a) Rainfall, (b) solar radiation, (c) water table for PS-41, and (d) water table for PS-43.

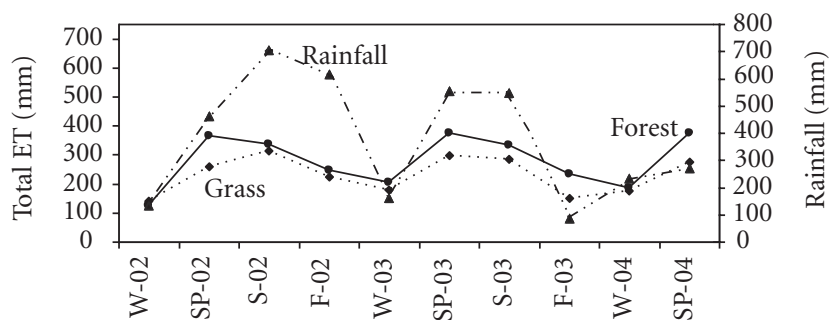

FIgURE 7: Variation in total ET for grass and forest land covers.

from year to year. Infiltration and runoff components, on the other hand, varied significantly depending on available

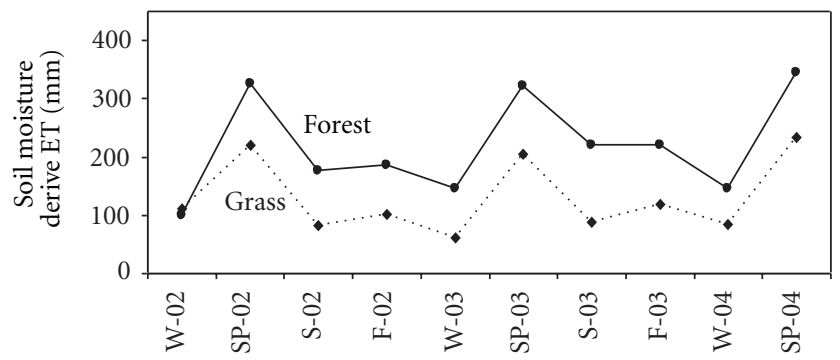

FIGURE 8: Variations of ET derived from soil moisture changes for grass and forest land covers.

precipitation and quarterly ET. For instance, rainfall magnitude in the summer of 2002 was about $200 \mathrm{~mm}$ more than 


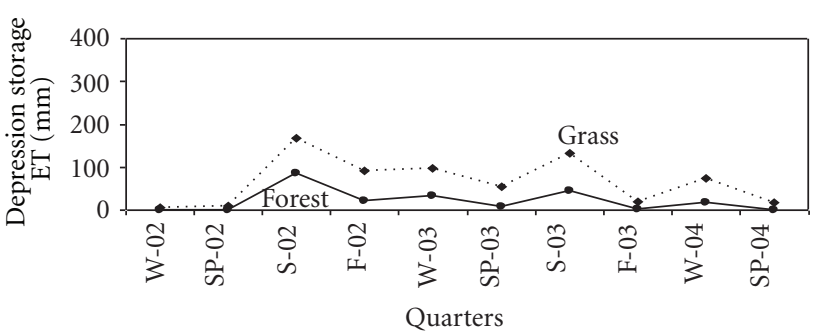

FIgURE 9: Variation of depression storage ET and forest land covers.

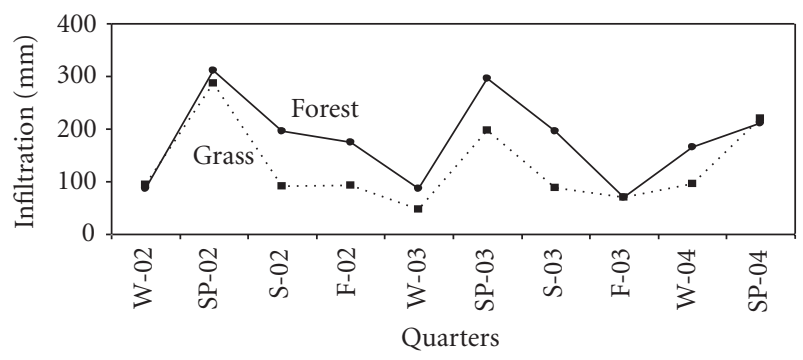

FIGURE 10: Variation of infiltration for grass and forest land covers.

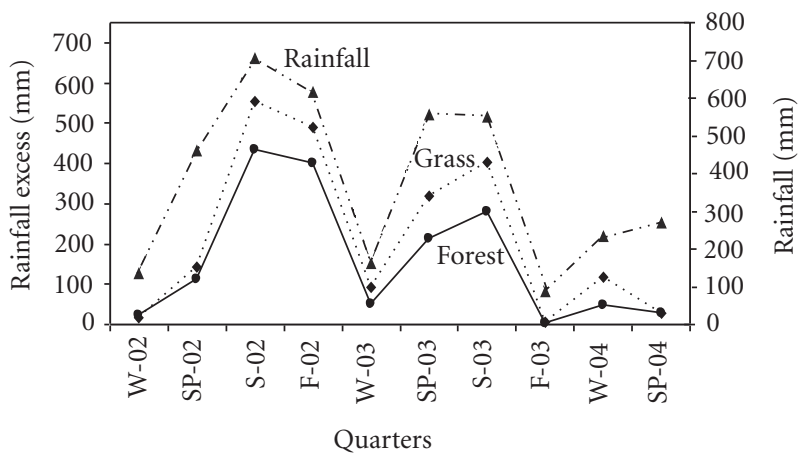

FIGURE 11: Rainfall excess for grass and forest land covers.

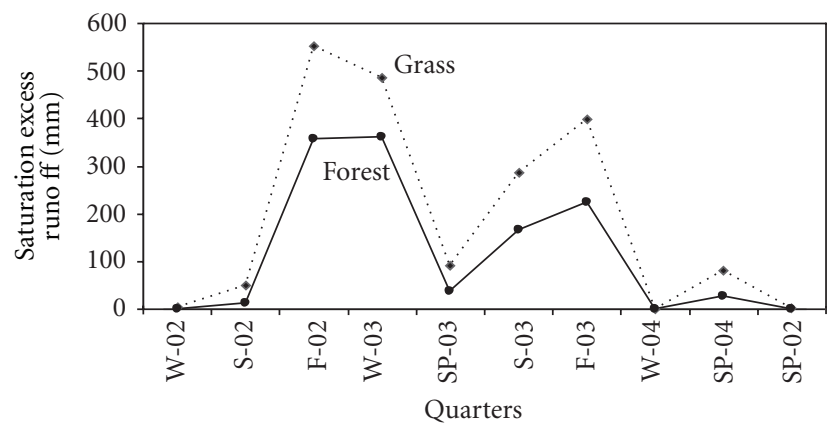

FIGURE 12: Saturation excess rainfall variation for grass and forest land covers.

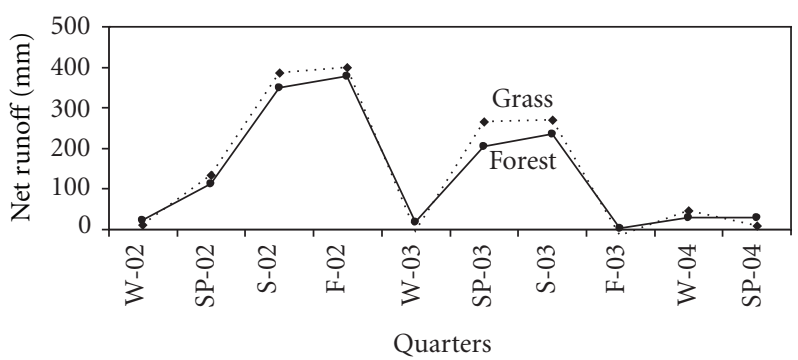

FIGURE 13: Net runoff for grass and forest land covers.

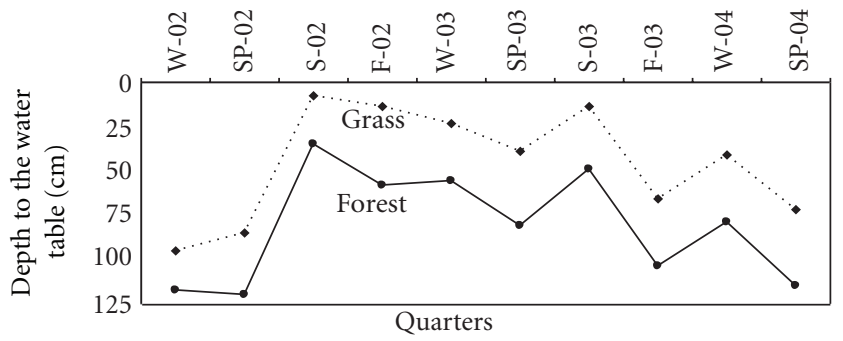

Figure 14: Variation in depth to the water table for grass and forest land covers.

that observed during summer 2003 (Figure 7). However, the corresponding ET demand for both grassland and forest cover behaved pretty much the same. This shows that under normal or wet conditions ET is strictly a function of ambient atmospheric conditions, while runoff is directly proportional to both the amount of precipitation occurring during a particular quarter and the magnitude of the ET in that period. This conclusion holds significance for predictive modeling, wherein models for runoff behavior must be expected to simulate strong seasonally varying ET behavior to insure predictive capability.

Annual observed water budget components in the two land cover environments in 2002, 2003, and six months for 2004 are summarized in Tables 3, 4, and 5, respectively. A clear trend in seasonal and annual behavior of the water budget components is observed for the upland versus near stream region. The upland grassland, with corresponding lower ET, exhibits higher runoff annually than the downslope forested land cover. This result is supported by the shallower $d_{\mathrm{WT}}$ exhibited by the grassed upland (Figure 14).

Various components of ET also revealed variability corresponding to land use regime. During dry periods a relatively uniform magnitude of total ET (TET) is observed across the transect wells for each landuse cover. The highest magnitude of TET was observed in the spring, followed by summer periods regardless of the land use covers. DS ET magnitude was considerably higher for the upland area (exhibiting shallower $d_{\mathrm{WT}}$ ) than near the stream region. This behavior was most pronounced in the summer (wet season) across transect wells and can be attributed to shallower $d_{\mathrm{WT}}$ in corresponding periods.

Concerning results obtained from the current analysis, it can be stated that evapotranspiration, to a significant degree, 
TABle 3: Annual water budget for 2002.

\begin{tabular}{|c|c|c|c|c|c|c|c|c|c|}
\hline $\begin{array}{l}\text { Land } \\
\text { use }\end{array}$ & Wells & $\begin{array}{l}\text { Rain } \\
(\mathrm{mm})\end{array}$ & $\mathrm{ET}(\mathrm{mm})$ & Runoff (mm) & $\begin{array}{c}\text { Lateral } \\
\text { flow } \\
(\mathrm{mm})\end{array}$ & $\begin{array}{l}\text { Infiltration } \\
\quad(\mathrm{mm})\end{array}$ & $\begin{array}{c}\text { Depth to } \\
\text { water } \\
\text { table } \\
(\mathrm{cm})\end{array}$ & $\begin{array}{c}\text { Change } \\
\text { in storage } \\
(\mathrm{mm})\end{array}$ & $\begin{array}{c}\text { Mass } \\
\text { balance } \\
\text { error } \\
(\mathrm{mm})\end{array}$ \\
\hline
\end{tabular}

\begin{tabular}{|c|c|c|c|c|c|c|c|c|c|c|c|c|c|c|c|c|}
\hline & ID & $\mathrm{P}$ & $I_{c}$ & $\begin{array}{l}\text { SM } \\
\text { ET }\end{array}$ & $\begin{array}{l}\text { DS } \\
\text { ET }\end{array}$ & TET & TRE & SRE & HR & URI & NR & $q$ & $I$ & $d_{\mathrm{WT}}$ & $S$ & $e$ \\
\hline Grass & USF-3 & 1914 & 147 & 514 & 344 & 1005 & 1231 & 1113 & 118 & 282 & 888 & $0^{*}$ & 536 & 45 & 212 & 0 \\
\hline Grass & USF-1 & 1914 & 147 & 516 & 287 & 950 & 1143 & 1111 & 32 & 235 & 856 & $0^{*}$ & 624 & 41 & 223 & 0 \\
\hline Grass & PS-43 & 1914 & 147 & 521 & 195 & 863 & 1235 & 1050 & 185 & 220 & 1040 & 23 & 532 & 71 & 247 & 45 \\
\hline Mixed & PS-42 & 1914 & 121 & 746 & 145 & 1012 & 1034 & 908 & 126 & 303 & 889 & 13 & 759 & 77 & 307 & -20 \\
\hline Forest & PS-41 & 1914 & 221 & 690 & 171 & 1082 & 1055 & 904 & 151 & 300 & 884 & 14 & 638 & 70 & 237 & 2 \\
\hline Forest & PS-40 & 1914 & 197 & 877 & 8 & 1082 & 816 & 383 & 433 & 396 & 808 & 9 & 900 & 109 & 374 & -9 \\
\hline Forest & PS-39 & 1914 & 197 & 882 & 17 & 1096 & 819 & 404 & 415 & 399 & 802 & -2 & 898 & 93 & 374 & -18 \\
\hline
\end{tabular}

* Insignificant.

TABle 4: Annual water budget for 2003.

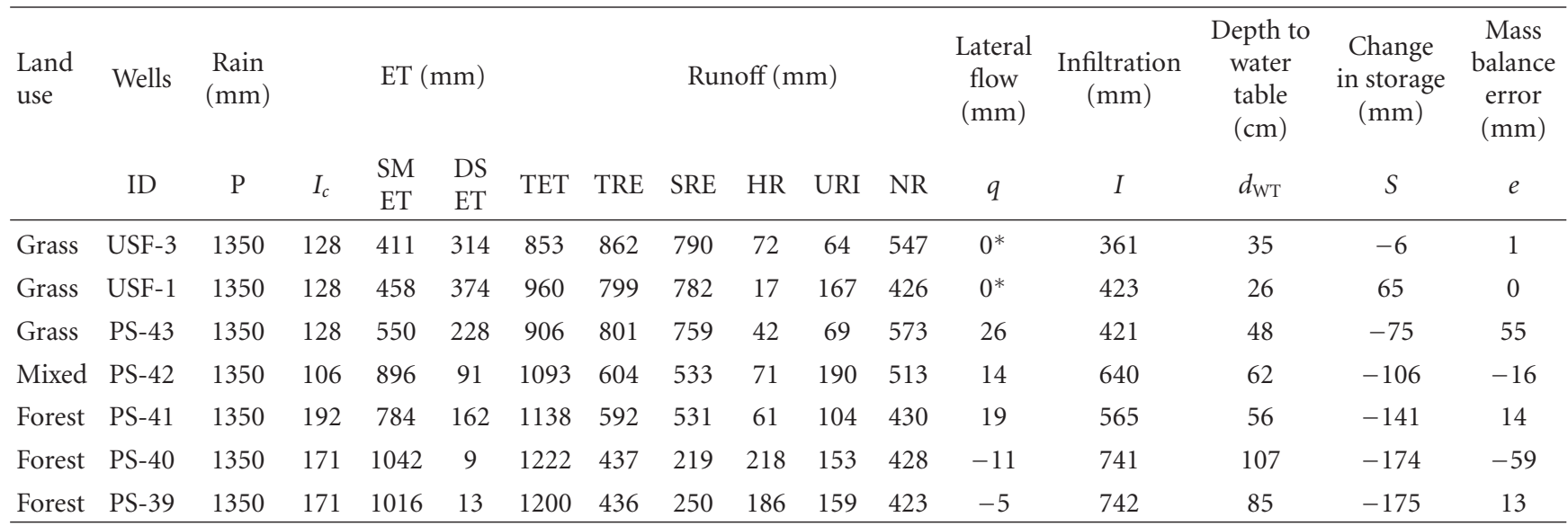

* Insignificant.

TABle 5: Semiannual water budget for 2004.

\begin{tabular}{|c|c|c|c|c|c|c|c|c|c|c|c|c|c|c|c|c|}
\hline \multirow{2}{*}{$\begin{array}{l}\text { Land } \\
\text { use }\end{array}$} & \multirow{2}{*}{$\begin{array}{c}\text { Wells } \\
\text { ID }\end{array}$} & \multirow{2}{*}{$\begin{array}{c}\text { Rain } \\
(\mathrm{mm}) \\
\text { P }\end{array}$} & \multirow[b]{2}{*}{$I_{c}$} & \multicolumn{3}{|c|}{$\mathrm{ET}(\mathrm{mm})$} & \multicolumn{5}{|c|}{ Runoff (mm) } & \multirow{2}{*}{$\begin{array}{c}\text { Lateral } \\
\text { flow } \\
(\mathrm{mm}) \\
q\end{array}$} & \multirow{2}{*}{$\begin{array}{c}\text { Infiltration } \\
(\mathrm{mm}) \\
I\end{array}$} & \multirow{2}{*}{$\begin{array}{l}\text { Depth to } \\
\text { water } \\
\text { table } \\
(\mathrm{cm}) \\
d_{\mathrm{WT}}\end{array}$} & \multirow{2}{*}{$\begin{array}{l}\text { Change } \\
\text { in storage } \\
(\mathrm{mm}) \\
S\end{array}$} & \multirow{2}{*}{$\begin{array}{c}\text { Mass } \\
\text { balance } \\
\text { error } \\
(\mathrm{mm}) \\
e\end{array}$} \\
\hline & & & & $\begin{array}{l}\text { SM } \\
\text { ET }\end{array}$ & $\begin{array}{l}\text { DS } \\
\text { ET }\end{array}$ & TET & TRE & SRE & $\mathrm{HR}$ & URI & NR & & & & & \\
\hline Grass & USF-3 & 502 & 42 & 382 & 127 & 551 & 182 & 129 & 53 & 86 & 55 & $0^{*}$ & 278 & 46 & 195 & 0 \\
\hline Grass & USF-1 & 502 & 42 & 388 & 124 & 554 & 142 & 49 & 93 & 126 & 18 & $0^{*}$ & 319 & 45 & 58 & 0 \\
\hline Grass & PS-43 & 502 & 42 & 384 & 25 & 451 & 112 & 71 & 41 & 134 & 87 & 10 & 348 & 84 & 135 & 20 \\
\hline Mixed & PS-42 & 502 & 34 & 499 & 27 & 560 & 98 & 51 & 47 & 162 & 71 & 7 & 370 & 82 & 20 & -7 \\
\hline Forest & PS-41 & 502 & 62 & 437 & 28 & 527 & 93 & 34 & 59 & 133 & 64 & 7 & 347 & 87 & 42 & 0 \\
\hline Forest & PS-40 & 502 & 56 & 538 & 0 & 594 & 35 & 0 & 35 & 176 & 35 & -4 & 412 & 132 & 5 & -21 \\
\hline Forest & PS-39 & 502 & 56 & 525 & 0 & 581 & 35 & 1 & 34 & 177 & 34 & -3 & 412 & 111 & 6 & 3 \\
\hline
\end{tabular}

* Insignificant. 


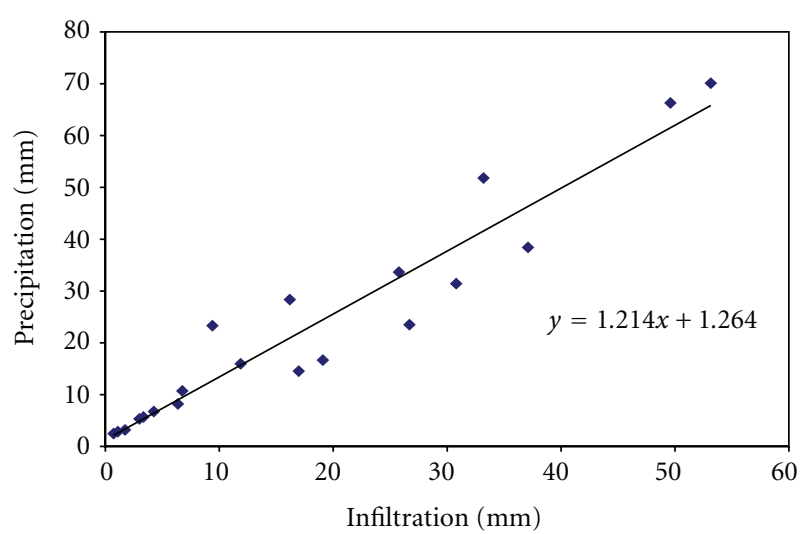

(a)

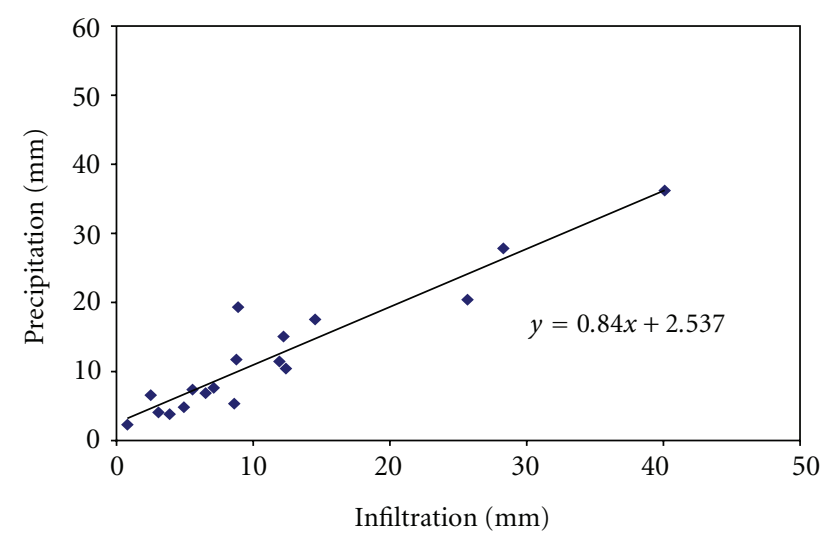

(b)

Figure 15: Precipitation versus Infiltration for (a) grassed land cover and (b) forested land cover, shown with equation of the best fit line.

controls all the surface and subsurface fluxes. Forest land cover has higher consumptive use of water resulting in lower elevation of the water table, as compared to the water table in the upland region. This condition, supported by the observed values, causes the initiation of lateral flux, whose magnitude is governed by the head difference between the upland and wetland (near stream) water table. At the same time, due to deeper water table and consequently dryer soil conditions in the vadose zone, the infiltration value is higher for forested land cover, thereby decreasing the total rainfall excess and runoff as compared to the upland grassed environment.

Also, interesting observations can be made concerning the diurnal behavior. In the night, as ET subsides, the lateral (and small vertical upward) flow is observed to partially replenish the water table as well as the vadose zone. Interestingly, from Figures 6(c) and 6(d) it can be seen that during the night time the water table elevation in the well in the forested area (PS41) rises, while in PS43 (grassed upland section) the water table, due to lateral flux out of the column, still shows decline. This observation is typical of the observation between the recharge and discharge regions (as previously noted by $[3,22,32])$.
The values of ET obtained from the current study are consistent with the numbers found by other studies, also done in Florida, including Sumner [1], Sumner [6], Bidlake et al. [4], and Knowles [5], for land covers similar to the ones present at the study site. On an average, ET has been found to vary between 60 and $70 \%$ of the long-term average precipitation occurring in the area and the observations made from this study support previous finding. However, as pointed out earlier, for higher than normal precipitation, the ET rates do not necessarily increase, hence, for years that are wetter than normal, the percentage of ET is substantially lower. In the current study, 2002 was an abnormally wet year with annual recorded precipitation of about $2000 \mathrm{~mm}$ as compared to average annual values of $1300-1500 \mathrm{~mm}$. This resulted in the percentage fraction of ET dropping from $70 \%$ to about $50 \%$. However the absolute magnitude of ET was very consistent from year to year.

The consistency of the results across different years coupled with similarities to previous studies helps to validate the current methodology as an optional approach. The small mass balance errors seen from the water budget table (Tables 3-5) can be attributed to error in the measurements as well as the assumption of impermeable lower boundary conditions. However the error is considered negligible as compared to the values of other components of the water budget (see Section 3.1 for discussion on the error estimates).

The biggest advantage of this method lies in comprehensiveness with which one can estimate all water budget components and seasonal or shorter time-scale variation. Also, localized land cover/soil type study site can be analyzed. Observations of ET components, derived plant coefficients, and other variables should prove extremely useful for improving the predictive capabilities of comprehensive surface and groundwater models. Also, the method is relatively inexpensive and does not require large area of uniformity in contrast to the other methods such as eddy correlation method (e.g., [1]).

3.1. Error Estimates. Finally, it is very important to also comment about the error ranges of the equipment as well as error estimates of other hydrologic properties determined for the study site and their possible effects on the magnitude of derived hydrologic components.

Section 2.2 mentions that the soil moisture observations as well as water table measurements are good to $0.1 \%$ water content and have been tested by manual measurements hence assuming the error to be random the net effect on the final results is expected to be negligible. Next the methodology is sensitive to the values of hydraulic conductivities and the associated effects on the lateral flow calculations. Section 2.3.1 discussed determination of hydraulic conductivity for this study. Both permeameter analysis and slug tests yielded gave values which were within $10-15 \%$. Owing to the relatively small values of lateral flow, even if the hydraulic conductivities were assumed to be variable around 10$15 \%$, the final water budget (Tables 3-5) lateral flux values would only change by less than $10 \mathrm{~mm}$ thereby having an 
insignificant effect on the annual as well as seasonal variation of the other water budget components.

Another factor that has the potential to introduce error is the choice of model for calculation of potential evapotranspiration. The selection of Jensen and Haise [30] method was done primarily for convenience in lieu of the availability and quality of metrological data. Use of standardized Penman Montieth equation requires a whole suite of weather parameters and for this particular study the data were not consistently and continuously available. Irmak et al. [33] compared different methods of ET estimation versus the Penman Montieth method and found that Jensen and Haise method fluctuated on either side with a general error of less than $15 \%$. Hence, the depression storage ET as well as net runoff is expected to reflect this error and therefore could vary by $\pm 15 \%$. On summing the values by quarter, the errors are expected to ultimately cancel or there would be a net bias which should be considerable less than the potential error magnitude $( \pm 15 \%)$. Therefore, due to the fractional contribution of DSET towards total ET estimates, the values of TET can be easily expected to be within a confidence bound of $\pm 5 \%$. As far as total rainfall excess, infiltration, and other water budget components are concerned, PET is not used in their calculation and hence the error associated with the choice of PET is not expected to be present in the final estimates.

Similarly the fluctuation in the value of interception capture which is around $10 \%$ of total ET values is not expected to appreciably change the final results for all components, save perhaps the runoff estimates which will directly reflect error estimates in interception capture.

Therefore, the overall results obtained from this analysis are within acceptable error limits $(\sim 5-10 \%)$ for this particular study. Given that the methodology attempts to comprehensively determine all the water budget components, this is believed insignificant. The consistency in the values of ET and other water budget components calculated for other similar environments (e.g., $[1,4,6]$ ) further increases confidence in the obtained results.

\section{Conclusion}

A one-dimensional transect model coupled with highly resolved soil moisture profile and water table monitoring was developed to determine magnitude and variation of different components of the water budget. Two and a half years of observed soil moisture and water table elevation data were used to derive all lateral and vertical fluxes comprising evapotranspiration components. The results successfully showed the variation of different fluxes with varying land cover and ambient weather conditions. Results also indicate a long-term consistency in seasonality of different fluxes with short time scale differences occurring due to differences in antecedent conditions. ET was found to be a dominant factor controlling surface and subsurface fluxes including runoff and water table recharge, second only to precipitation. Lateral flow was found to be less than $2 \%$ of the precipitation in the annual water budget. Thus, the performance of the methodology and model response in regions with higher lateral flow (and vertical leakage) settings is worthy of further evaluation. This aspect of the investigation is ongoing and results will be forthcoming.

The methodology used in the study, unlike other methods, such as eddy correlation or solar-radiation-based methods, gives a direct estimate of the soil moisture and water extracted by the roots and, hence, is expected to yield better plant-based ET parameters such as plant coefficients. The method excels at determining component fluxes such as ET, lateral flow, and rainfall excess (runoff). Even though the current study considered land cover variations, it did not take into account plant specifics like rooting depths, leaf area index, and so forth, which are known to affect the lateral and vertical fluxes for a given land cover and are key modeling parameters. Some attempt needs to be made to incorporate these variables in the observations. The main drawback of the above methodology is that if the water table gets deeper than the deepest soil moisture sensors, errors in the calculation of storage changes can over or underpredict fluxes. This could be a problem in deep water table environments. Another limitation occurs when the water table is very shallow. For these periods ET must be assumed to be equal to potential ET which is believed to be an acceptable assumption for water table at or near land surface [29]. However actual PET measurement is problematic [34]. Due to continuous surface replenishment resolution of soil ET flux cannot be made during these times. Error in PET estimation will therefore be reflected in ET estimates during these periods.

Lastly, the reliability of the method is only achieved if sensors penetrate the deepest depths of soil moisture uptake. Another important aspect that is relevant for the applicability of this methodology pertains to different hydrogeological settings and determination of vertical leakage. For the study site as the confining layer, separating the surficial aquifer with the intermediate aquifer was intact, contiguous, and relatively thick; therefore, the assumption of negligible leakage across the lower boundary was appropriate; however in higher leakage environments vertical leakage will be another variable which must be solved for these environments in the mass balance equation (1). It is believed that night time declines can be separated from day time decline in the manner of Nachabe et al. [3] to still render this method effective for estimating water budget components. However, for improved reliability this will need to be further tested on high leakage environments.

\section{Acknowledgments}

The work was made possible through continued funding and support from Tampa Bay Water, the Southwest Florida Water Management District, and the US Geological Survey.

\section{References}

[1] D. M. Sumner, "Adequacy of selected evapotranspiration approximations for hydrologic simulation," Journal of the American Water Resources Association, vol. 42, no. 3, pp. 699711, 2006.

[2] M. Ross, A. Said, J. Geurink, P. Tara, and A. Aly, "Evapotranspiration hierarchy and allocation for integrated surface and 
groundwater model in West-Central Florida," Hydrological Science and Technology, vol. 21, no. 1-4, pp. 157-176, 2005.

[3] M. Nachabe, N. Shah, M. Ross, and J. Vomacka, "Evapotranspiration of two vegetation covers in a shallow water table environment," Soil Science Society of America Journal, vol. 69, no. 2, pp. 492-499, 2005.

[4] W. R. Bidlake, W. M. Woodham, and M. A. Lopez, "Evapotranspiration from areas of native vegetation in Wets- Central Florida," United States Geological Survey Open File Report 93415, 1993.

[5] L. Knowles Jr., "Estimation of evapotranspiration in the Rainbow Springs and Silver Springs basin in north-central Florida," Water Resources Investigation Report 96-4024, United States Geological Survey, Reston, Va, USA, 1996.

[6] D. M. Sumner, "Evapotranspiration from a cypress and pine forest subjected to natural fires, Volusia County, Florida, 1998-99," Water Resources Investigations Report 01-4245, United States Geological Survey, Reston, Va, USA, 2001.

[7] J. Doorenbos and W. O. Pruitt, "Crop water requirements," FAO Irrigation and Drainage Paper 24, Food and agricultural organization of the United Nations, Rome, Italy, 1977.

[8] H. L. Penman, "Natural evaporation from open water, bare soil, and grass," Proceedings of Royal Society of London A, vol. 193, no. 1032, pp. 120-146, 1948.

[9] C. W. Thornthwaite, "An approach toward a rational classification of climate," Geographic Review, vol. 38, pp. 55-94, 1948.

[10] J. L. Monteith, "Evaporation and environment," in The State and Movement of Water in Living Organisms, G. E. Fogg, Ed., pp. 205-234, Symposium of the Society of Experimental Biology, San Diego, Calif, USA; Academic Press, New York, NY, USA, 1965.

[11] C. H. B. Priestley and R. J. Taylor, "On the assessment of surface heat flux and evaporation using large-scale parameters," Monthly Weather Review, vol. 100, no. 2, pp. 81-92, 1972.

[12] W. Brutsaert, Evaporation into the Atmosphere: Theory, History, and Applications, Kluwer Academic Publishers, Boston, Mass, USA, 1982.

[13] M. J. Fayer and D. Hillel, "Air encapsulation: I. Measurement in a field soil," Soil Science Society of America Journal, vol. 50, no. 3, pp. 568-572, 1986.

[14] J. Yang, B. Li, and L. Shiping, "A large weighing lysimeter for evapotranspiration and soil-water-gr oundwater exchange studies," Hydrological Processes, vol. 14, no. 10, pp. 1887-1897, 2000.

[15] G. W. Kite and P. Droogers, "Comparing evapotranspiration estimates from satellites, hydrological models and field data," Journal of Hydrology, vol. 229, no. 1-2, pp. 3-18, 2000.

[16] X. Mo, S. Liu, Z. Lin, and W. Zhao, "Simulating temporal and spatial variation of evapotranspiration over the Lushi basin," Journal of Hydrology, vol. 285, no. 1-4, pp. 125-142, 2004.

[17] A. Fares and A. K. Alva, "Evaluation of capacitance probes for optimal irrigation of citrus through soil moisture monitoring in an entisol profile," Irrigation Science, vol. 19, no. 2, pp. 5764, 2000.

[18] A. Robock, K. Y. Vinnikov, G. Srinivasan et al., "The global soil moisture data bank," Bulletin of the American Meteorological Society, vol. 81, no. 6, pp. 1281-1299, 2000.

[19] R. Mahmood and K. G. Hubbard, "Simulating sensitivity of soil moisture and evapotranspiration under heterogeneous soils and land uses," Journal of Hydrology, vol. 280, no. 1-4, pp. 72-90, 2003.

[20] V. W. Carlisle, F. Sodek, M. E. Collins, L. C. Hammond, and
W. G. Harris, "Characterization data for selected Florida soils," Soil Survey Report, United States Department of Agriculture, Washington, DC, USA, 1989.

[21] D. L. Thompson, Specific Yield Variability and the Evolution of Ground Water Evapotranspiration in Humid Shallow Water Table Environment, M.S. thesis, Department of Civil and Environmental Engineering. University of South Florida, Tampa, Fla, USA, 2003.

[22] K. Trout and M. Ross, "Intensive hydrologic data collection in a small watershed in Wet-Central Florida," Hydrological Science and Technology, vol. 21, no. 1-4, pp. 187-197, 2005.

[23] HDR and Tampa Bay Water, "Geotechnical site characterization report_tampa bay regional reservoir volume I," LAW Project 40120-8-0106, 1999.

[24] P. Buss, "The use of capacitance based measurements of real time soil water profile dynamics for irrigation scheduling," in Proceedings of the National Conference of the Irrigation Association of Australia and the Australian National Committee on Irrigation and Drainage, Irrigation Association of Australia, Lauceston, Australia, May 1993.

[25] K. T. Morgan, L. R. Parsons, T. A. Wheaton, D. J. Pitts, and T. A. Obreza, "Field calibration of a capacitance water content probe in fine sand soils," Soil Science Society of America Journal, vol. 63, no. 4, pp. 987-989, 1999.

[26] A. Said, M. Nachabe, M. Ross, and J. Vomacka, "Methodology for estimating specific yield in shallow water environment using continuous soil moisture data," ASCE Journal of Irrigation and Drainage Engineering, vol. 131, no. 6, pp. 533-538, 2005.

[27] H. Bower and R. C. Rice, "A slug test for determining the hydraulic properties of tight formations," Water Resources Research, vol. 16, no. 1, pp. 233-238, 1980.

[28] M. J. Hvorslev, "Time lag and soil permeability in ground water observations," Bulletin, no. 36, p. 50, 1951.

[29] N. Shah, M. Nachabe, and M. Ross, "Extinction depth and evapotranspiration from ground water under selected land covers," Ground Water, vol. 45, no. 3, pp. 329-338, 2007.

[30] M. E. Jensen and H. R. Haise, "Estimation of evapotranspiration from solar radiation," Journal of Irrigation and Drainage Division, Proceedings of the American Society of Civil Engineers, vol. 89, pp. 15-41, 1963.

[31] W. Viessman Jr. and G. Lewis, Introduction to Hydrology, Pearson Education, Upper Saddle River,NJ, USA, 5th edition, 2002.

[32] R. Freeze and J. Cherry, Groundwater, Prentice Hall, Old Tappan, NJ, USA, 1979.

[33] S. Irmak, A. Irmak, R. G. Allen, and J. W. Jones, "Solar and net radiation-based equations to estimate reference evapotranspiration in humid climates," ASCE Journal of Irrigation and Drainage Engineering, vol. 129, no. 5, pp. 336-347, 2003.

[34] R. G. Allen, I. A. Walter, R. L. Elliot et al., The ASCE Standardized Reference Evapotranspiration Equation, American Society of Civil Engineers, Reston, Va, USA, 2005. 

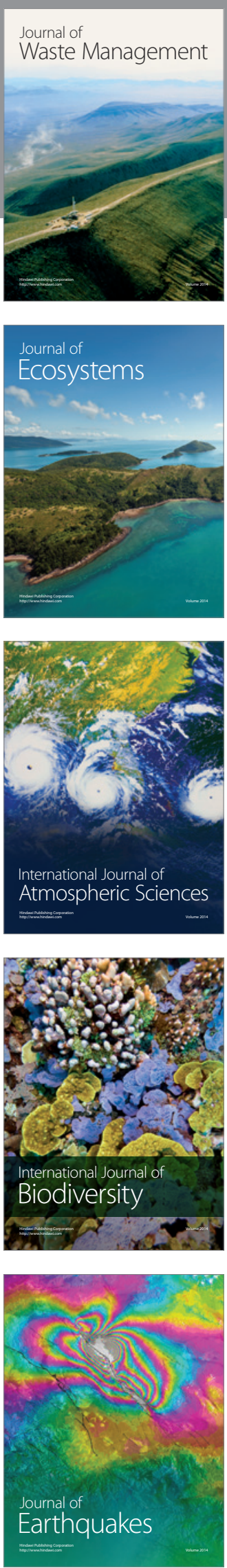
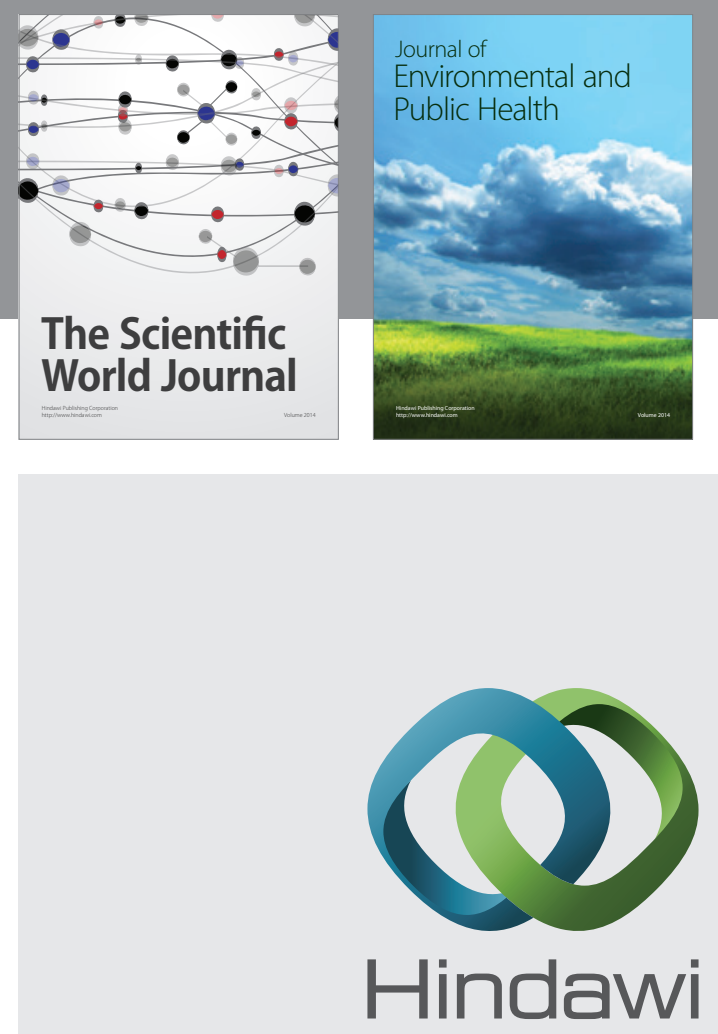

Submit your manuscripts at

http://www.hindawi.com
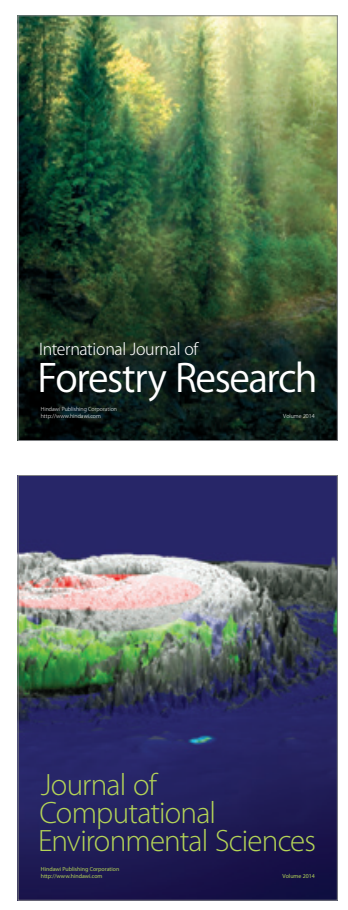
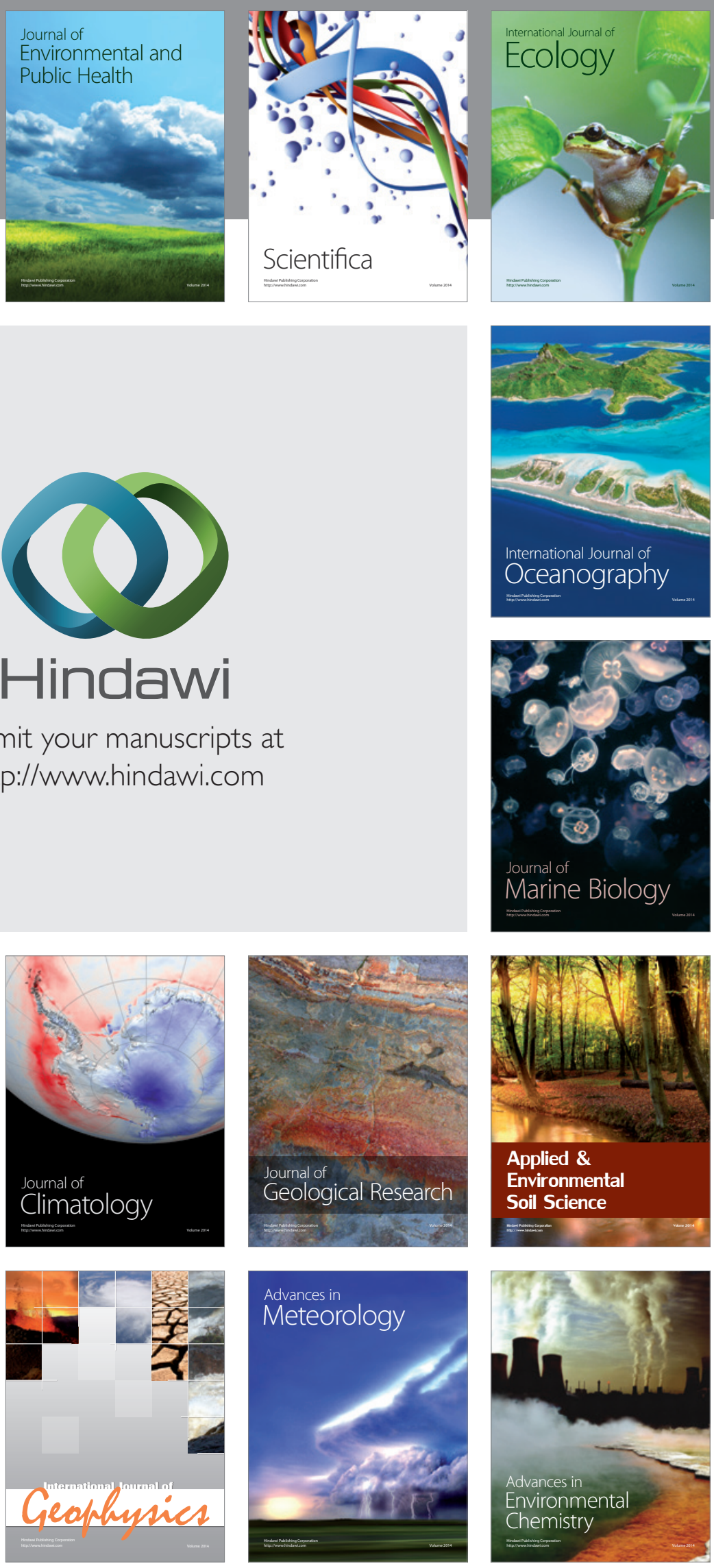